\title{
MOLECULAR DIAGNOSTICS IN INDUSTRY: SOURCES OF PETRI DISEASE IN GRAPEVINE NURSERIES
}

\author{
S.A. WHITEMAN, M.V. JASPERS, A. STEWART and H.J. RIDGWAY \\ Soil, Plant and Ecological Sciences Division, PO Box 84, Lincoln University, \\ Canterbury \\ Corresponding author: whitemas@lincoln.ac.nz
}

\begin{abstract}
Phaeomoniella chlamydospora, a fungal pathogen of woody grapevine tissue, causes Petri disease. Petri disease is observed as poor growth and decline of vines and could threaten the long-term sustainability of winegrape production in New Zealand. One potential source of the fungus is the grafting process. Grafting involves five major steps, collection of plant material, hydration and fungicide treatment prior to storage, rehydration prior to grafting, grafting and callusing in a growth medium. Thirty to forty liquid samples were collected from each step and tested for the presence of P. chlamydospora DNA using a highly specific, highly sensitive molecular marker. DNA of the pathogen was found at all stages of the grafting process with the percentage of positive samples ranging from 13 to $50 \%$. Levels were highest in processes were there was repeated exposure to cutting material, that is hydration/fungicide treatment, rehydration prior to grafting and grafting tools. These sources of the pathogen may be reduced or eliminated by improved hygiene regimes and any biological or chemical control agents that become available. The molecular technology described has the potential to form the basis of a much needed diagnostic service.
\end{abstract}

\section{EVALUATION OF BIOFUMIGANTS AND TRICHODERMA PRODUCTS FOR SUPPRESSION OF SOIL-BORNE PATHOGENS ON POTATOES}

\author{
L-H CHEAH ${ }^{1}$, K.G. TATE ${ }^{2}$, S. BUTCHER ${ }^{3}$ and B. McINTOSH ${ }^{3}$
}

\author{
${ }^{1}$ New Zealand Institute for Crop \& Food Research Limited, Private Bag 11600, \\ Palmerston North \\ ${ }^{2}$ Crop Health Service, PO Box 2153, Stortford Lodge, Hastings \\ ${ }^{3}$ McCain Foods (NZ) Ltd, PO Box 502, Feilding \\ Corresponding author: cheahl@crop.cri.nz.
}

Two field trials were carried out, one at each of two commercial potato growers' properties at Opiki, to evaluate the efficacy of BQ Mulch (a brassica crop grown for its biofumigant properties) and four Trichoderma products (Tri-D25, Trichogrow, Rootshield and $\mathrm{DRHCl}$ ) for the biological control of major soil-borne diseases of potatoes. BQ Mulch was grown for 60 days, rotary-hoed into the soil and allowed to decompose for one week before potatoes were planted. Trichoderma products were sprayed onto seed pieces during the planting operation. Compared with untreated plots, Tri-D25 reduced percentage of tubers with pink rot caused by Phytophthora erythroseptica while BQ mulch did not. Tri-D25, Trichogrow and DRHCI all gave similar low levels of pink rot but the differences were not significant. BQ Mulch appeared to increase rots caused by Fusarium and Phytophthora spp. A field trial is in progress to further test the efficacy of Trichoderma products against soil-borne pathogens of potatoes. 